\title{
Spectrophotometric Micro determination of Silver(I) using Meloxicam as a New Analytical Reagent
}

\author{
REEM KAMAL SHAH \\ Chemistry Department, College of Applied Sciences, \\ Umm Al-Qura University, Makkah 21955, Saudi Arabia. \\ *Corresponding author E-mail: reem.shah @ hotmail.com \\ http://dx.doi.org/10.13005/ojc/320157
}

(Received: December 22, 2015; Accepted: February 03, 2016)

\begin{abstract}
A new chromogenic reagent, meloxicam was used for highly sensitive, selective and rapid method for the determination of silver based on the rapid reaction of silver(I) with meloxicam. In the presence acetate buffer solution of $\mathrm{pH} 4.6$ and Triton X-100 as an optimum medium, meloxicam reacts with silver to form a yellow complex of molar ratio 1:1 (silver to meloxicam). The molar absorptivity of the formed complex was calculated to be $1.124 \times 10^{4} \mathrm{~L} \mathrm{~mol}^{-1} \mathrm{~cm}^{-1}$ at $412 \mathrm{~nm}$. Beer's law is obeyed in the range of $1.0-15.0 \mu \mathrm{g} \mathrm{mL}^{-1}$. The relative standard deviation for six replicate samples of $7.0 \mathrm{\mu g} \mathrm{mL}^{-1}$ was $1.33 \%$. The limits of detection and quantification were also calculated. Finally the repeatability, accuracy and the effect of interfering ions on the determination of silver ion were evaluated. The method was applied successfully for determination silver in some water samples.
\end{abstract}

Key words: Silver determination; Spectrophotometry; Meloxicam; Water samples.

\section{INTRODUCTION}

Silver and its compounds have an essential role in electronic and electrical applications, photographic film production, dental and pharmaceutical preparations, and manufacturing of fungicides ${ }^{1,2}$. Silver is also used for the preparation of high-strength and corrosion-resistance alloys and jewelry. These widespread applications have resulted in an increased silver content of the environmental samples. Silver can also enter the environment via industrial waters because it is often an impurity in zinc, copper, antimony, and arsenic ores ${ }^{3}$. On the other hand, silver has been recognized as a toxic element to many aquatic organisms even at low concentrations ${ }^{4}$. Moreover, $\mathrm{Ag}$ accumulation in the human body may lead to a permanent blue-gray skin discoloration (known as Argyria), and the threshold values regulating the maximum amount of silver permitted in different kinds of samples have been established in many countries ${ }^{5}$. Therefore, its trace determination in water and environmental samples is important. There are different methods for $\mathrm{Ag}(\mathrm{I})$ determination, like, high performance liquid chromatography $(\mathrm{HPLC})^{6}$, atomic absorption spectrometry (AAS) ${ }^{7,8}$, 
kinetic $^{9-12}$, capillary zone electrophoresis $(\mathrm{CZE})^{13}$, flow injection analysis (FIA) ${ }^{14}$, fluorimetric ${ }^{15}$ and spectrophotometric ${ }^{16-28}$. Spectrophotometric methods still the most commonly used tools due to the common availability of instrumentation, the simplicity, speed and the accuracy of the technique still make spectrophotometric methods attractive. Meloxicam, 4-hydroxy-2-methyl-N(5-methyl-2-thiazolyl)-2-H-1,2benzothiazine-3-carbox-amide -1,1-dioxide [Fig. 1] is a non-steroidal anti-inflammatory drug ${ }^{29}$ which also acts as a green chelating agent for many metal ions. In this work, we used spectrophotometric method in order to determine silver for the first time using a meloxicam as a chelating agent. The advantages of the proposed method, with respect to previous ones, are that highly selective, fairly sensitive, simple, rapid, economical and may be safely applied to $\mathrm{Ag}(\mathrm{I})$ determination in different real samples in order to discover its possibilities for further applications.

\section{EXPERIMENTAL}

\section{Apparatus}

All the absorption spectra measurements were carried out using a SHIMADZO UV-VIS-NIR spectrophotometer (model UV-3600) with a scanning speed $400 \mathrm{~nm} / \mathrm{min}$, slit width $2.0 \mathrm{~nm}$ and equipped with $10 \mathrm{~mm}$ matched quartz cells. The $\mathrm{pH}$ of all solutions was adjusted to the required value using $\mathrm{pH}$-meter (HANA instruments; model HI 8014).

\section{Chemicals}

All the chemical reagents employed were of analytical grade and the solutions were prepared with bidistilled water. A stock solution of $10^{-2} \mathrm{M}$ silver(I) nitrate was prepared by weighing $0.157 \mathrm{~g}$ of $\left(\mathrm{AgNO}_{3}\right.$, Merck) and dissolved in least amount of water and then completed in a $100 \mathrm{~mL}$ measuring flask to the mark with bidistilled water. A stock solution of $10^{-3}$ $\mathrm{M}$ of meloxicam (a gift from ADWC Company, Cairo) was prepared by dissolving $0.03517 \mathrm{~g}$ in absolute ethanol. Acetate buffer solutions were prepared according to the previous procedure of Gomori ${ }^{30}$

\section{General procedure}

An aliquot of $A g(I)$ standard solution was transferred to $10 \mathrm{~mL}$ measuring flask, $1.0 \mathrm{~mL}$ of 1 $x 10^{-3} \mathrm{M}$ meloxicam solution, $0.6 \mathrm{~mL}$ of and $1.0 \mathrm{~mL}$ acetate buffer solution of $\mathrm{pH} 4.6$ were mixed well. The solution was completed up to the mark with bidistilled water and allowed to stand for $2 \mathrm{~min}$. The absorbance of the formed yellow complex was measured at 412 $\mathrm{nm}$. The blank solution was prepared by the same procedure without silver ion. All the measurements were performed at room temperature.

\section{Determination of stoichiometry}

The experiments for the determination of the stoichiometry of $\mathrm{Ag}(\mathrm{I})$-meloxicam complex was conducted using a UV-Vis spectrometry. Job's method of continuous variation was applied to establish the components ratio of the complexes. For this, different volumes $(0.2,0.4,0.6,0.8,1.0$, $1.2,1.4,1.6,1.8,2.0 \mathrm{~mL})$ of $1.0 \times 10^{13} \mathrm{M} \mathrm{Ag}(\mathrm{I})$ was added to different volumes $(1.8,1.6,1.4,1.2,1.0$, $0.8,0.6,0.4,0.2,0 \mathrm{~mL})$ of $1.0 \times 10^{\prime \prime} \mathrm{M}$ meloxicam at optimum conditions and diluted to the volume with bidistilled water in $10 \mathrm{~mL}$ standard volumetric flask. The absorbance was recorded at wavelength $412 \mathrm{~nm}$ and plotted against the mole fraction of $\mathrm{Ag}(\mathrm{I})$. The complex stoichiometry was found from the graphs obtained and the conditional stability constant of this complex was calculated using the Harvey and Manning method ${ }^{31}$.

\section{Determination of silver(I) in real samples}

The studied method was successfully applied to the determination of silver(I) in some water samples. The water samples were analyzed as follows: $500 \mathrm{~mL}$ of water samples in a $1.0 \mathrm{~L}$ flask was concentrated to about $50 \mathrm{~mL}$ by heating on a hot plate. After that, addition of $10 \mathrm{~mL}$ of concentrated nitric acid and $2 \mathrm{~mL}$ of $30 \%$ hydrogen peroxide, then heat on hot plate till evaporated and emitting large white smoke. Add $2 \mathrm{~mL}$ of perchloric acid, Evaporated to near dryness. Dissolve the residue with $5 \mathrm{~mL}$ of $5 \%$ of nitric acid and transferred into a measuring flask. The obtained solution was neutralized with sodium hydroxide and analyzed by the developed method. The recovery of silver(I) by adding standard known amounts of silver(I) in water samples was carried out, applying the method of standard addition.

\section{RESULTS AND DISCUSSION}

\section{Absorption spectra}

The absorption spectra of meloxicamsilver(I) complex in acetate buffer solution of $\mathrm{pH} 4.6$ were recorded against a meloxicam and buffer as a blank. Meloxicam shows a maximum absorbance at 
$367 \mathrm{~nm}$. The formation of silver(I)-meloxicam yellow complex was accompanied with bathochromic shift of $\ddot{e}_{\max }$ to $412 \mathrm{~nm}$, [Fig. 2]. Optimization was carried out to variables permitting measurements in order to establish the most favorable conditions. These conditions were optimized by fixing all parameters to be constant and optimizing one at a time. The influence of each of the following variables on the reaction was tested.

\section{Effect of $\mathrm{pH}$}

The most convenient solution $\mathrm{pH}$ on the spectrophotometric determination of the silvermeloxicam complex was investigated using different types of buffers (acetate $3.0-6.0)$, borate (8.0 - 10.0), phosphate (5.8 - 8.0) and universal (1.93 12.7). The suitable one was the acetate buffer. After mixing $1.0 \mathrm{~mL}$ of $1 \times 10^{-3} \mathrm{M}$ meloxicam solution, 0.6 $\mathrm{mL}$ of and $4.0 \mathrm{~mL}$ acetate buffer of different $\mathrm{pH}$, Fig. 3 reflects highest absorbance value in extremely narrow $\mathrm{pH}$ range (3.3 - 5.0), outside which a decline in absorbance was observed. Obviously, $\mathrm{pH} 4.6$ seems to be the appropriate choice as optimum $\mathrm{pH}$. Also amount of buffer was investigated as shown in Fig. 4. $1.0 \mathrm{~mL}$ acetate buffer gave a highest absorbance, so all subsequent studies were performed using $1.0 \mathrm{~mL}$ buffer at $\mathrm{pH}$ 4.6.

\section{Effect of reagent concentration}

The concentration of meloxicam has a significant effect on the absorbance of the formed

Table 1: Optimum condition parameters of $\mathrm{Ag}(\mathrm{I})$ complex with meloxicam

\begin{tabular}{lc}
\hline Parameters & Ag(I)-meloxicam \\
\hline Type of buffer & Acetate \\
Working $\mathrm{pH}$ & 4.60 \\
Volume of buffer, $\mathrm{mL}$ & 1.00 \\
$\lambda_{\max }(\mathrm{nm})$ & 412 \\
Conc of reagent, M & $1.0 \times 10^{-3}$ \\
Sequence of addition & $\mathrm{R}-\mathrm{M}-\mathrm{B}$ \\
Optimum time (min) & 2 \\
Stoichiometric ratio (M:L) & $(1: 1)$ \\
Stability constant & 11.22 \\
\hline
\end{tabular}

R: Meloxicam, B: Buffer, M: Silver

a Stability constant using continuous variation method3.5. The stoichiometric ratio of the formed complex complex with $\mathrm{Ag}(\mathrm{I})$ which was investigated in the range of $(0.5-6.0) \times 10^{-4} \mathrm{M}$. It can be seen from Fig. 5 that the absorbance increases with an increase in the meloxicam concentration up to $2.0 \times 10^{-4} \mathrm{M}$, above which it starts to decline. Therefore $2.0 \times 10^{-4}$ $\mathrm{M}$ of meloxicam was selected for further work.

\section{Effect of the sequence of addition}

It is important to study the sequence of the addition of species formed the studied complex by measuring the absorbance of the formed complex using different sequence of addition against the blank solution prepared by the same manner without including $\mathrm{Ag}(\mathrm{I})$. The best sequence was determined from the highest absorbance value. The optimal sequence of addition was found [R-M-B]. All the optimal conditions are shown in Table (1).

The nature of the studied complex was determined at the above optimum conditions using continuous variation method. The Jop's method<smiles>Cc1cnc(NC(=O)C2=C(O)c3ccccc3S(=O)(=O)N2C)s1</smiles>

Fig. 1: The structure of meloxicam

Table 2: Tolerance limits for the determination of $7.0 \mu \mathrm{g} \mathrm{mL}^{-1}$ of $\mathrm{Ag}(\mathrm{I})$ using meloxicam (accepted relative error $\pm 5.0 \%$ )

\section{Foreign ion added The tolerance limit}

\begin{tabular}{lc}
\hline $\mathrm{Br}^{-}, \mathrm{Ba}^{2+}, \mathrm{K}^{+}, \mathrm{Na}^{+}$, acetate, $\mathrm{Bi}^{3+}$ & 1500 \\
$\mathrm{Cr}^{4+}, \mathrm{Li}^{+}, \mathrm{Cl}^{-}, \mathrm{Oxalate}^{2+} \mathrm{Mn}^{2+}$ & 1200 \\
$\mathrm{Au}^{3+}, \mathrm{Ca}^{2+}, \mathrm{Mg}^{2+}, \mathrm{Sr}^{2+}, \mathrm{I}^{-}, \mathrm{Br}$ & 650 \\
$\mathrm{~W}^{6+}, \mathrm{U}^{4+}, \mathrm{S}^{2-}$ & 500 \\
$\mathrm{Ni}^{2+}, \mathrm{F}^{-}, \mathrm{Fe}^{2+}, \mathrm{Al}^{3+}, \mathrm{Fe}^{3+}, \mathrm{Mo}^{6+}$ & 300 \\
$\mathrm{Ti}^{4+}, \mathrm{Cr}^{6+}, \mathrm{Zr}^{4+}$ & 150 \\
$\mathrm{Cd}^{2+}, \mathrm{Pd}^{2+}, \mathrm{Zn}^{2+}, \mathrm{Cu}^{2+}$ & 100 \\
$\mathrm{Sn}^{4+}, \mathrm{Pb}^{2+}, \mathrm{Hg}^{2+}$ & 50 \\
$\mathrm{Cr}^{3+}, \mathrm{La}^{3+}, \mathrm{Co}^{2+}$ & 30 \\
$\mathrm{Se}^{4+}, \mathrm{Te}^{4+}, \mathrm{Zr}^{4+}$ & 10 \\
$\mathrm{Th}^{4+}, \mathrm{V}(\mathrm{V})$, & \\
\hline
\end{tabular}


indicated an inflection at a mole fraction of 0.5 of $\mathrm{Ag}(\mathrm{I})$ [Fig. 6] which gave evidence that the stoichiometric ratio of $\mathrm{Ag}(\mathrm{I})$-meloxicam was (1:1). Moreover, the formation constant [log k], calculating using the Harvey and Manning equation, applying the data obtained from continuous variation method, was found to be 11.22 .

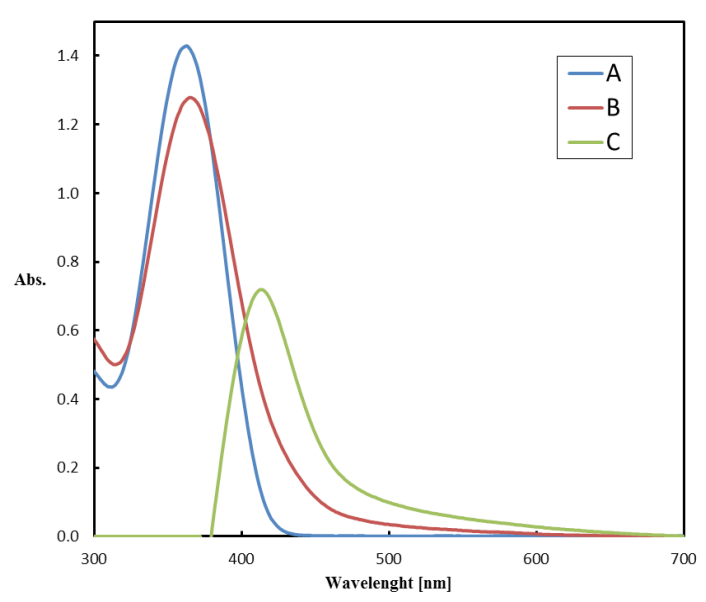

Fig. 2: Absorption spectra of the reagent meloxicam with $A g(I)$ where $A$ : meloxicam + buffer against buffer $B$ : meloxicam $+\mathbf{A g}(\mathrm{I})$ +buffer against buffer, $\mathrm{C}$ : meloxicam + Ag(l) +buffer against reagent + buffer

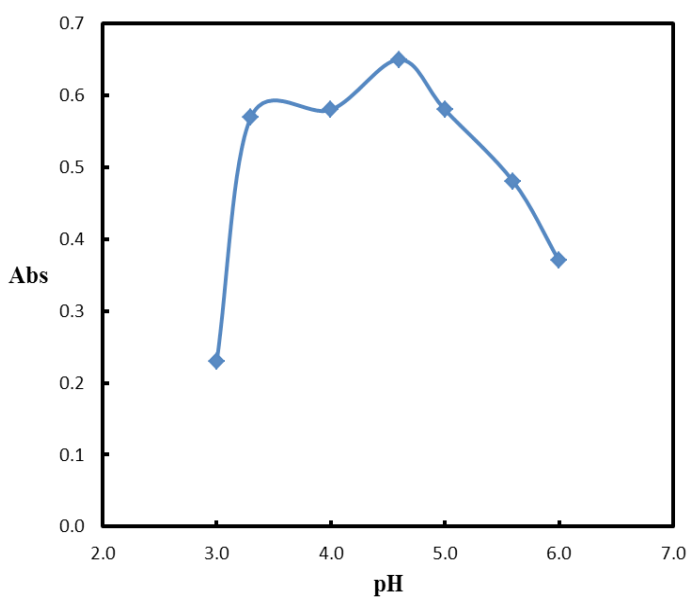

Fig. 3: Effect of $\mathrm{pH}$ on the absorbance for the complex formed between $1 \times 10^{-4} \mathrm{M}$ meloxicam and $1 \times 10^{-4} \mathrm{M}$ silver(I) using acetate buffer

\section{Interference studies}

The effect of foreign ions on the determination of $7.0 \mu \mathrm{g} \mathrm{mL}^{-1}$ of $\mathrm{Ag}(\mathrm{I})$ by the proposed method was examined. The tolerable amount of each ion was taken as an Ag: interference ratio that caused an error not exceeding $\pm 5 \%$ in the absorbance value of the solution. Results showed that about a 300-1500 fold excess of $\mathrm{Br}-, \mathrm{Ba}^{2+}, \mathrm{K}^{+}, \mathrm{Na}^{+}$, acetate, $\mathrm{Bi}^{3+}, \mathrm{Cr}^{4+}$, $\mathrm{Li}^{+}, \mathrm{Cl}^{-}$, oxalate, $\mathrm{Mn}^{2+}, \mathrm{Au}^{3+}, \mathrm{Ca}^{2+}, \mathrm{Mg}^{2+}, \mathrm{Sr}^{2+}, \mathrm{I}^{-}, \mathrm{Br}$, $\mathrm{W}^{6+}, \mathrm{U}^{4+}, \mathrm{S}^{2-}, \mathrm{Ni}^{2+}, \mathrm{F}^{-}, \mathrm{Fe}^{2+}, \mathrm{Al}^{3+}, \mathrm{Fe}^{3+}, \mathrm{Mo}^{6+} \mathrm{Ti}^{4+}, \mathrm{Cr}^{6+}$ and $\mathrm{Zr}^{4+}$ showed no interference. As given in Table 2, $\mathrm{Th}^{4+}$ and $\mathrm{V}^{5+}$ observed interfere resulting in positive errors, so these interferences should be eliminated using nitric acid.

\section{Analytical characteristics Linearity}

The calibration curve for the determination of $\mathrm{Ag}(\mathrm{I})$ by its reaction with meloxicam was constructed by plotting the absorbance as a function of the corresponding concentrations $\left(\mu \mathrm{g} \mathrm{mL}^{-1}\right)$. The regression equation for the results was $A=0.0692$ $\mathrm{C}-0.053$ with a correlation coefficient $\mathrm{R}^{2}=0.9992$, where $A$ is the absorbance at $412 \mathrm{~nm}, C$ is the concentration of silver $(\mathrm{I})$ in igmL" in the range of 1.0-15.0 ig mL"1. [Fig. 7]. The molar absorptivity (å) was $1.124 \times 10^{4}$. For more accurate analysis, Ringbom plot for optimum concentration range was obtained. Statistical analysis of the results obtained

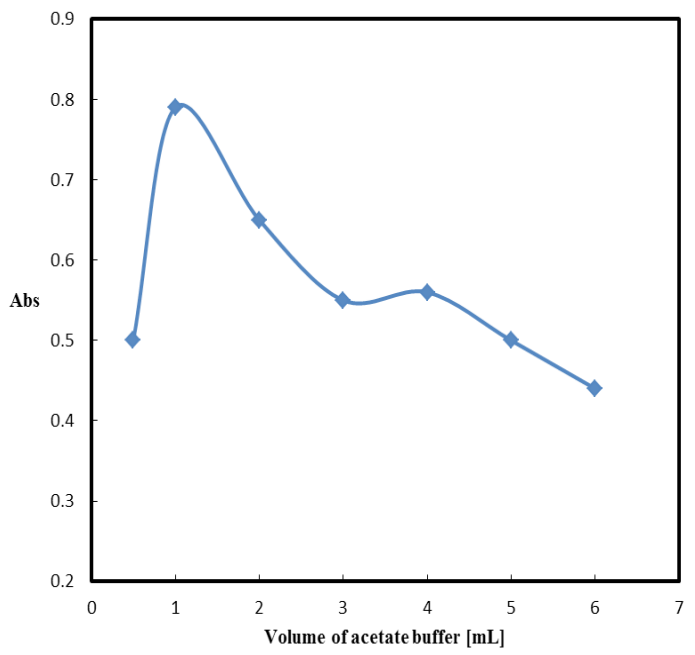

Fig. 4: Effect of acetate buffer volume of pH 4.6 on the absorbance of complex formed between $1 \times 10^{-4} \mathrm{M}$ meloxicam and $1 \times 10^{-4} \mathrm{M}$ silver(I) 
(Table 3), indicated that the proposed procedure was accurate and precise. The precision of the proposed method was determined by analyzing six replicate samples of standard silver(I) solution at one concentration level, . The assay gave satisfactory results; the relative standard deviation (RSD) was $1.33 \%$ indicating good reproducibility of the proposed methods. This precision level is adequate for the precision and routine analysis of silver $(\mathrm{I})$ in quality control laboratories.

\section{Sensitivity}

Based on the IUPAC's recommendation, the detection limit (LOD) for the proposed method was calculated using the following equation

$$
\mathrm{LOD}=3.3 \mathrm{~s} / \mathrm{k}
$$

Table 3: Cumulative data of the analytical conditions for spectrophotometric determination of $\mathrm{Ag}(\mathrm{I})$ with meloxicam

\begin{tabular}{|c|c|}
\hline Parameters & $\begin{array}{c}\text { Ag(I) } \\
\text { Meloxicam } \\
\text { complex }\end{array}$ \\
\hline Color & Yellow \\
\hline $\mathrm{pH}$ & 4.60 \\
\hline$\lambda_{\max }(n m), A$ curve & 367 \\
\hline$\lambda_{\max }(n m), B$ curve & 375 \\
\hline$\lambda_{\max }(\mathrm{nm}), \mathrm{C}$ curve & 412 \\
\hline Beer's law range,$(\mathrm{mg} / \mathrm{mL})$ & $1.0-15.0$ \\
\hline Ringbom range ,(mg/mL) & $2.5-12.5$ \\
\hline Detection limit, $\left(\mathrm{mg} \mathrm{mL}^{-1}\right)$ & 0.296 \\
\hline Quantification limit, $\left(\mathrm{mg} \mathrm{mL}^{-1}\right)$ & 0.889 \\
\hline Standard deviation (SD) & 0.0934 \\
\hline Relative standard deviation (RSD), \% & 1.33 \\
\hline Variance $\times 10^{-3}$ & 8.72 \\
\hline Error \% & 2.13 \\
\hline \multicolumn{2}{|l|}{${ }^{\star}$ Regression equation } \\
\hline Slope (b) & 0.069 \\
\hline Intercept (a) & 0.053 \\
\hline Correlation coefficient & 0.9992 \\
\hline Molar absorptivity, $\left(\mathrm{L} \mathrm{mol}^{-1} \mathrm{~cm}^{-1}\right)$ & $1.124 \times 10^{4}$ \\
\hline Sandell's sensitivity $\left(\mathrm{ng} \mathrm{cm}^{-2}\right)$ & 14.49 \\
\hline aConfidence limit & $7 \pm 0.093$ \\
\hline
\end{tabular}

${ }^{*} A=a+b C$, where $C$ is the concentration of $\mathrm{Ag}(\mathrm{I})$ in $\mathrm{g} \mathrm{L}^{-1}$

${ }^{a}$ Confidence limit after six replicate measurements at $95 \%$ confidence level where $s$ is the standard deviation of replicate determination values under the same conditions as for the sample analysis in the absence of the silver(I) and $k$ is the sensitivity, namely the slope of the calibration curve. In accordance with the formula, the detection limit was found to be 0.296 igmL"1 which indicate high sensitivity of the proposed methods (Table 3).

The limit of quantification, $L O Q$, is defined as

$$
\mathrm{LOQ}=10 \mathrm{~s} / \mathrm{k}
$$

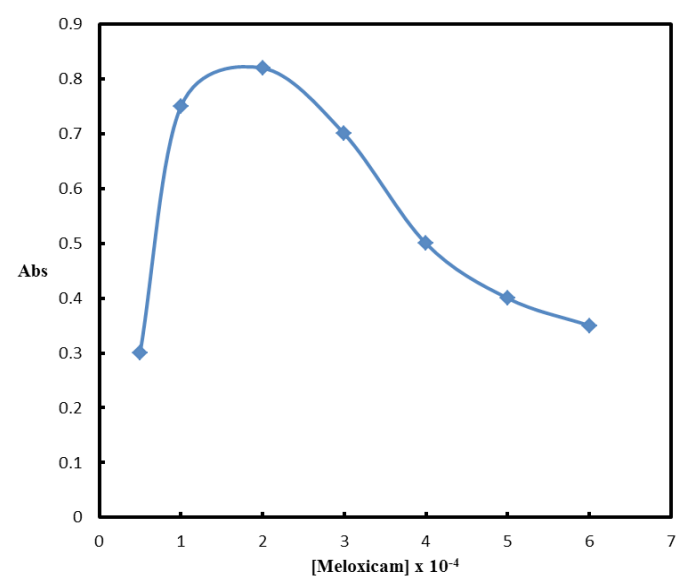

Fig. 5: Effect of meloxicam concentration on the complexation of $1 \times 10^{-4} \mathrm{M}$ meloxicam and 1 $x 10^{-4} \mathrm{M}$ silver(I) in acetate buffer of $\mathrm{pH} 4.6$

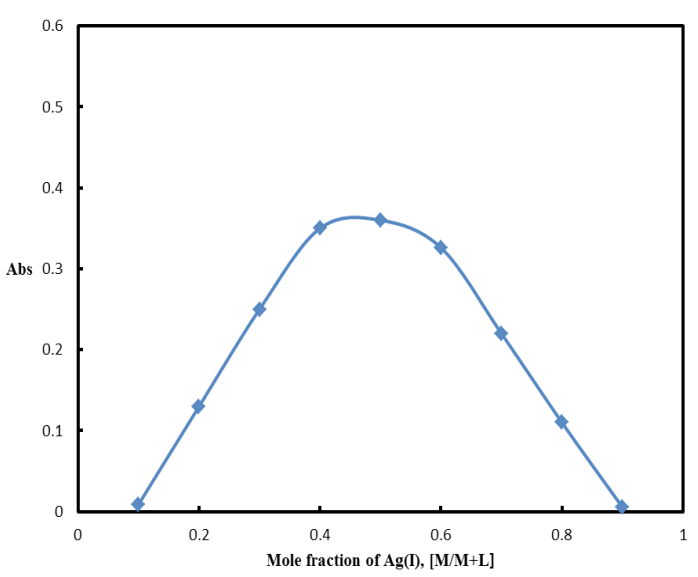

Fig. 6: Job's plot for determination of stoichiometry of the reaction between silver(I) and meloxicam $[\mathrm{Ag}(\mathrm{I})]: 1 \times 10^{13} \mathrm{M}$; [meloxicam] $1 \times 10^{\prime 3} \mathrm{M} ;[\mathrm{Ag}(\mathrm{I})]+[$ meloxicam $]: 2.0 \mathrm{~mL}$ at $\mathrm{pH}$ 4.6 using acetate buffer 
According to Eqn, the limit of quantization was found to be $0.889 \mu \mathrm{g} \mathrm{mL}^{-1}$.

The percentage relative error was calculated using the following equation:

Error\% $=[($ founded " added $) /$ added $] \times 100$ and was found to be $2.13 \%$.
These above results indicating good accuracy and precision of the proposed method show that this method has good repeatability and reproducibility.

\section{Analytical application}

Aiming to demonstrate the usefulness of the developed method, a set of samples containing

Table 4: Analytical application of silver(I) in water samples using the proposed method

\begin{tabular}{|c|c|c|c|c|c|}
\hline \multirow[t]{2}{*}{ Sample } & \multicolumn{3}{|c|}{$A g(I), \mu g \mathrm{~mL}^{-1}$} & \multicolumn{2}{|r|}{ Recovery (\%) } \\
\hline & Added & Found & $t$ - test & F- value & 土 RSD \\
\hline \multirow[t]{3}{*}{ Tape water } & -- & 1.91 & - & - & - \\
\hline & 2 & 4.03 & 2.01 & 1.52 & $106 \pm 1.07$ \\
\hline & 4 & 5.89 & 1.45 & 2.58 & $99.5 \pm 2.11$ \\
\hline \multirow[t]{3}{*}{ Waste water } & - & 11.82 & - & - & -- \\
\hline & 1 & 12.78 & 2.22 & 4.75 & $107 \pm 1.77$ \\
\hline & 2 & 13.88 & 0.82 & 1.87 & $103 \pm 1.92$ \\
\hline \multirow[t]{3}{*}{ Well water } & - & ND & - & - & - \\
\hline & 3 & 3.03 & 1.69 & 3.45 & $101 \pm 0.97$ \\
\hline & 5 & 4.98 & 1.35 & 2.48 & $99.6 \pm 1.13$ \\
\hline
\end{tabular}

a Obtained from the drinking water system of Makkah, Saudia.

${ }^{b}$ Waste water collected from processing of photographic films Lab.

${ }^{b}$ At $95 \%$ confidence level, the theoretical $t$ - and F-values for five degree of freedom are 2.78 and 6.26 , respectively.

ND: Not detected

Table 5: Comparison of reagents for spectrophotometric determination of silver

\begin{tabular}{|c|c|c|c|c|c|}
\hline Reagent & $\begin{array}{c}\mathrm{pH} / \\
\text { Surfactant }\end{array}$ & $\begin{array}{c}\lambda_{\max } \\
(\mathrm{nm})\end{array}$ & $\begin{array}{c}\mathrm{e} \mathrm{x} / 10^{4} \\
\mathrm{Lmol}^{-1} \mathrm{~cm}^{-1}\end{array}$ & $\begin{array}{l}\text { Linear range } \\
\qquad\left(\mu \mathrm{gmL}^{-1}\right)\end{array}$ & Ref. \\
\hline $\begin{array}{l}\text { 2-(5-Chloro-2-pyridylazo)- } \\
\text { 5-diethylaminoaniline }\end{array}$ & $\begin{array}{l}(\mathrm{pH} 10) \\
\text { SDS }\end{array}$ & 530 & 6.7 & $0.05-1.2$ & {$[32]$} \\
\hline Thio-Michler's ketone & $\begin{array}{l}(\mathrm{pH} 5) \\
\text { SDS }\end{array}$ & 535 & 9.4 & $0.0-0.4$ & [33] \\
\hline $\begin{array}{l}\text { 2-(5-Bromo-2-pyridylazo)- } \\
\text { 5-dimethylaminophenol }\end{array}$ & $\begin{array}{l}(\mathrm{pH} 6.8-8) \\
\text { SDS }\end{array}$ & 542 & 6.5 & $0.1-1.6$ & {$[34]$} \\
\hline $\begin{array}{l}\text { 2-(3,5-Dibromo-2-pyridylazo)- } \\
\text { 5-diethylaminophenol }\end{array}$ & $\begin{array}{l}(\mathrm{pH} 5) \\
\text { SDS }\end{array}$ & 565 & 6.4 & $0.02-0.48$ & {$[35]$} \\
\hline $\begin{array}{l}\text { Sulfochlorophenolazo } \\
\text { Thiorhodanine }\end{array}$ & $\begin{array}{c}(\mathrm{pH} 2.8) \\
\text { Triton } \mathrm{X}-100\end{array}$ & 540 & 39.4 & $0.0-10.8$ & {$[36]$} \\
\hline $\begin{array}{l}\text { Tetra-(4-chlorophenyl)- } \\
\text { porphyrin }\end{array}$ & $\begin{array}{c}(\mathrm{pH} \mathrm{10}) \\
\text { TritonX-100 }\end{array}$ & 426 & 3.88 & $0.0-0.32$ & {$[37]$} \\
\hline Meloxicam & $\mathrm{pH} 4.6$ & 412 & 1.124 & $1.0-15.0$ & This work \\
\hline
\end{tabular}




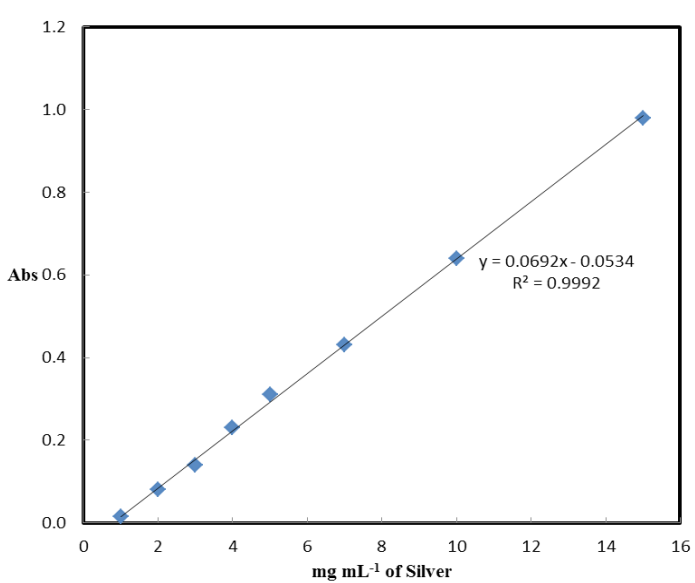

Fig. 7: Calibration curve for silver(I) determination using $2.0 \times 10^{-3} \mathrm{M}$ meloxicam at pH 4.6 using acetate buffer

different water samples was analyzed. The proposed method was successfully applied to the determination of silver(I) in tap and wastewater samples. The results were shown in Table 4. The recoveries are close to $100 \%$ and indicate that the proposed method was helpful for the determination of silver(I) in the real samples. The performance of the proposed method was determined by calculation of the student's $t$-value (for accuracy) and $F$-test (for precision) applying a standard addition method. The mean values were obtained in a Student's $t$ - and $F$-tests at 95\% confidence limits for five degrees of freedom. The results showed that the calculated values (Table 4) did not exceed the theoretical values reveal no significant difference in the performance of the two methods. A wider range of determination, higher accuracy, more stability and less time consuming, shows the advantage of the proposed method over other method.

\section{CONCLUSION}

Although various techniques were reported for the determination of $\mathrm{Ag}(\mathrm{I})$, this work presents the appropriate simplicity, (Table 5) sensitivity and selectivity for the determination of trace amount of $\mathrm{Ag}(\mathrm{l})$. This method is useful owing to the sufficient capability for the determination of $\mathrm{Ag}(\mathrm{I})$ ion in various water samples. Apart from the high sensitivity, the procedure is very simple, fast and gains a low detection limit without any complicated equipment. Furthermore, the method benefits from an acceptable reproducibility, which is comparable with well-known confident methods.

\section{REFERENCES}

1. M. Grayson, Kirk-Othmer Encyclopedia of Chemical Technology, 21, John Wiley \& Sons, New York, NY, USA, 3rd edition, 1980.

2. I. C. Smith and B. L. Carson, Trace Metals in the Environment, Ann Arbor Science Publishers, Ann Arbor, Mich, USA, 1977,2,

3. R. Soager, Metallic Raw Materials Dictionary, Bank Tobel, Zurich, Switzerland, 1984.

4. J. L. Manzoori, H. Abdolmohammad-Zadeh, and M. Amjadi, Ultra-trace determination of silver in water samples by electrothermal atomic absorption spectrometry after preconcentration with a ligand-less cloud point extraction methodology,p Journal of Hazardous Materials.2007,144,-2,458-463,

5. M. Resano, M. Aramend'ýa, E. Garc'ýaRuiz, C. Crespo, and M. A. Belarra, Solid sampling-graphite furnace atomic absorption spectrometry for the direct determination of silver at trace and ultratrace levels, Analytica Chimica Acta, 2006,571,1,142- 149.

6. L. Wang, Q. Hu, G. Yang, J. Yin, Z. Yuan, Online solid phase extraction reverse phase liquid chromatographic determination of lead, cadmium, silver and mercury in water, Fenxi Huaxue. (2004), 32,421-427 (in Chinese).

7. G. Chakrapani, P.L. Mahanta, D.S.R. Murty, B. Gomathy, Preconcentration of traces of gold, silver and palladium on activated carbon and its determination in geological samples by flame AAS after wet ashing, Talanta. (2001),53,1139-1147.

8. J. Pandey, P. Sudhakar, V.J. Koshy, Determination of silver at submicrogram levels by absorption spectrophotometry, Ind. J. Chem. Tech. (2003), 10,295-297.

9. G.M. Mastoi, A.A. Khaskheli, I.A. Ansari, M.Y. Khuhawar, Kinetic spectrophotometric 
determination of silver(I) by the catalytic effect on the oxidation of chromotropic acid by bromate, Paks. J. Chem. Soc.(1997),19, 273-278.

10. Yu.I. Grosse, A.D. Miller, Highly sensitive kinetic method for determination of silver in rocks, Metody Anal. Redkometal. Miner. Rud. Gorn. Porod.(1971), 2, 52-64.

11. V.K. Reddy, A. Chennaiah, P.R. Reddy, T.S. Reddy, Kinetic-photometric determination of silver(I) based on its catalytic effect on reaction between potassium ferrocyanide and 2-hydroxy-4-metoxybenzophenone thioemicarbazone, Chem Anal. (2003), 48, 733-740.

12. Yu.I. Grosse, A.D. Miller, Kinetic determination of silver in natural material, Zavodskaya Lab. (1974), 40,262-263.

13. M. Aguilar, A. Farran, M. Martinez, Determination of gold (I) and silver (I) cyanide in ores by capillary zone electrophoresis, J. Chromatogr.(1993),635, 127-131.

14. K. Fujimura, T. Odake, H. Takiguchi, N. Watanabe, T. Sawada, Flow injection spectrophotometric determination of sub $\mathrm{mg} / \mathrm{dm}^{3}$ silver in a strongly acidic solution containing concentrated copper(II) using a pyridylazo reagent, Anal. Sci.(2011), 27, 1197-1201.

15. V. Kabasakalis, Fluorimetric determination of silver by brilliant green in aqueous systems and its application in photographic fixing solutions, Anal. Lett. (1994), 27,2789-2798.

16. P. Nagaraja, M.S.H. Kumar, H.S. Yathirajan, Silver enhanced reduction of 2,3,5triphenyl-2 $\mathrm{H}$-tetrazolium by semicarbazide hydrochloride (SHC) for the spectrophotometric determination of traces silver(I), Anal. Sci. (2002), 18, 815-820.

17. C. Ivanova, S. Popova, Spectrophotometric determination of silver with brompyrogallol red (BPR) and 1,10-phenantroline in the presence of gelatin, J. Univ. Chem. Tech. Met (2002), 37, 33-38.

18. H.W. Gao, L. Wang, M. Tao, Primarysecondary wavelength spectrophotometric determination of trace amounts of silver in waste water with 2,4-dibromo-6-carboxybenzendiazoaminoazobenzene (DBCBAAB), Paks. J. Chem. Soc.(2000),22, 275-280.
19. S.G. Kawatkar, P.S. Manol, A simple and sensitive spectrophotometric method for determination of silver(I) with resacetophenone guanylhydrazone (RAG), Acta Cie. Ind.(1998), 24, 167-169.

20. S.Tsiouris, F. Aravanopoulos, I. Papadoyannis, M. Sofoniou, N. Polyzopoulos, M. Christodoulou, V. Samanidou, G. Zachariadis, H.Constantinidou, Soil silver content of agricultural areas subjected to cloud seeding with Agl, Frez. Env. Bull.(2002),11, 697702.

21. H.W. Gao, Reanalysis of silver chelate solution and determination of trace amounts of silver in waste water, Asian J. Chem. (1999), 11,740-745.

22. F. Salinas, A. Espinosa-Mansilla, A.P. Lopez de Alba, Extraction-spectrophotometric determination of silver in ores, electronic flow- solders and white metals with 2-carboxybenzaldehyde thiosemicarbazone (2CBTSC), Analyst.(1995), 120, 2857-2860

23. B.G., R.P., Singh, Determination of silver, platinum or gold and copper in ternary mixtures with potassium thiocarbonate, Analyst.(1982), 29, 85

24. Z. Fulong, Z. Hang, Different approaches to the determination of silver ion at low levels by flow injection analysis, Anal. Chem. Acta. (1988), 15,206-213.

25. N.N. Ischenko, L.I. Ganago, I.F. Ivanova, Flotation-spectrophotometric determination of silver, J. Anal. Chem.(1997), 52, 768-769

26. X.J. Guo, Q.L. Deng, B. Peng, J.Z. Gao, J.W. Kang, Catalytic spectrophotometric determination of ultratrace amounts of silver with solubilizing effect on nonionic surfacant, Chin. J. Chem. (2002), 20, 39-44

27. C. H. Shul and L. Chang, Spectrophotometric determination of silver with 2-(3,5-dibromo2-pyridylazo)-5-diethyl-aminophenol in the presence of anionic surfactant, Talanta,(1982), 29, 85- 88.

28. M. A. Kassem, Development of a cloud-point extraction method for spectrophotometric nano determination of silver in real samplesp, Anal. Meth., (2015), 7, 6747-6754.

29. Pairet M., Van-Ryn J., Schierok H., Mauz A., Trummlitz G., Engelhardt G., Differential inhibition of cyclooxygenases- 1 and -2 by 
meloxicam and its 42 -isomer, Inflammatory Res., , (1998), 47, 270

30. G. Gomori, "Mothods in Enzymology",(1955), 1, 141.

31. A.E.Harvey, D.L.Manning, "Spectrophotometric Methods of establishing empirical formulas of colored complexes in solution", J. Am. Chem. Soc., (1950), 72, 4488.

32. G. Xue, Huangjin Chin. J. Gold ,(1996), 17, 43-48.

33. K. M Liao, Fenxi Shiyanshi Chin. J. Anal. Lab.
(1985) ,4, 62-67.

34. L. H. Chai and X. J. Zhang, Fudan Daxue Xuebao, Fudan Univ. Acta,(1992) 31, 115120.

35. Y. L. Yang, G. Y. Yang, J. Y. Yin and Q. H. Xu, Lihua Jianyan Huaxue Fence, Chin. J. Phys. Chem. Anal.,(2000), 36, 157.

36. S. L Cheng, Fenxi Huaxue Chin. J. Anal. Chem.,(1992),20, 7.

37. Z. Y. Wang and X. Q. Zhu, Yejin Fenxi, Chin. J. Metall. Anal.,(1998), 18, 46. 